\title{
Construction of the Mode of Practical Training for Entrepreneurial Education in Colleges and Universities -Marketing Specialty Taken as Example
}

\author{
Wenli Li \\ College of Business Administration, Jilin Engineering Normal University, Changchun, China \\ 657010587@qq.com
}

Keywords: Entrepreneurial education; Practical Training; Marketing specialty; Construction; Mode

\begin{abstract}
In theface of some problems concerning entrepreneurial education, such as misunderstanding on the concept of entrepreneurial education, limited resources of entrepreneurial education, lack of systematic content in entrepreneurial education and lack of reasonable design and renovation of teaching methods, a design is put forward in this paper based on the consideration of practical training rooms in colleges and universities, the goal of cultivating "double-capable" students, the inclusion of quality of entrepreneurship into the goal system of talent cultivation by colleges and universities as well as the "trinity" of specialized practical training, practical training for entrepreneurial education and on-job practice in order to ensure that students can complete practical training for specialized courses, on-job practice in business objects and practical training for entrepreneurial education and thus their consciousness of innovation, quality of entrepreneurship and the ability to combine theoretical knowledge and practice can be cultivated in a better way.
\end{abstract}

\section{Introduction}

The educational circles have been attaching much important on entrepreneurial education [1], which not only can relieve the current employment pressure but also can be beneficial to cultivation of students' thought of entrepreneurship and quality and ability in entrepreneurial education in colleges and universities. Those special entrepreneurial bases or enterprises are definitely perfect places for practical training of students, but practical training rooms in most colleges and universities mainly serve as places used for specialized courses and practical teaching, due to which there are relatively obvious problems such as lack of off-campus entrepreneurial bases, limitation on number of students that can be accommodated by such bases, no guarantee for completion of entrepreneurship training and education by all students, limited site for entrepreneurial education and unsystematic nature of entrepreneurial education, so limited resources for practical entrepreneurial education restrict development of entrepreneurial education of colleges and universities in a serious way. Based on the abilities of all students in adaptation to various posts and their entrepreneurship, a mode of practical training for entrepreneurial education characterized by the trinity of "practical training + on-job practice + entrepreneurial practice" suitable for colleges and universities is put forward in this paper by relying on using practical training rooms, making the most of resources in such practical training rooms and integrating specialized knowledge and entrepreneurship knowledge in an overall way.

\section{Misunderstanding \& shortcomings Concerning Practice of Entrepreneurial Education in College and Universities}

Misunderstanding on Concept: Improvement of Entrepreneurial Education is Necessary Only to these Students with the Entrepreneurial Intention. Entrepreneurial education is deemed as a temporary measure for relieving employment pressure by some colleges and universities. Such short-sighted point of view and behavior will definitely cause the problem that entrepreneurial education becomes a mere formality. Not only can entrepreneurial education relieve employment pressure faced by students, it can also help students follow out the ability-oriented concept and 
include quality of students in entrepreneurship in the goal system of talent cultivation of colleges and universities and thus cultivate students' consciousness of innovation, independence and risk as well as the ability to effectively combine theoretical knowledge and practice [2], which is more important.

Lack of Systematic Content in Practical Training for Entrepreneurial Education and Lack of Reasonable Design \& Innovation of Teaching Methods. The phenomenon of disconnection between theories and practices is relatively obvious in teaching of entrepreneurship by colleges and universities, in which content in practical training for entrepreneurial education, as an imported item, hasn't been modified and localized based on conditions and development requirement of the Chinese market; courses of entrepreneurship training and specialized courses haven't been integrated into the talent cultivation program based on the goal of cultivating quality and ability of students; and entrepreneurship training and specialized knowledge were totally separated and disconnected. As for methods of practical training for entrepreneurial education, design and innovation haven't been realized based on characteristics of different stages of development of entrepreneurship by using scientific and standard methods, so teaching methods for practical entrepreneurship training are outmoded and monotonous.

Failure in Meeting Requirements of Practical Training by Using Limited Resources of Practical Training for Entrepreneurial Education. Generally, practical entrepreneurial trainings are conducted in entrepreneurial bases or realized through simulated training by using entrepreneurial software, for which there are various problems such as the excessive number of students, limited resources in entrepreneurial bases, monotonous training subjects, insufficient intensity and frequency of trainings and lack of systematic nature of such trainings. In addition, upgrading of entrepreneurial software lags behind and there are relatively obvious differences between scenarios in such software and the actual situation of market, due to which such software can't provide much guidance to students. Teachers serving as instructors of entrepreneurial practice lack actual experiences in market and most of these teachers are only academically capable in this aspect.

\section{Construction of the Mode of Practical Training for Entrepreneurial Education Based on the Trinity of "Practical Training + On-job Practice + Entrepreneurial Practice"}

Goals of Cultivation. Teaching resources should be efficiently used to realize effective integration of practical training for entrepreneurial education [3]. "Double-capable" students who are adaptable to specific jobs and have the entrepreneurial ability should be cultivated, for which specialty of Marketing is taken as the example in this paper. Through the construction of the practical training mode of entrepreneurial education based on the trinity of "practical training + on-job practice + entrepreneurial practice" and the starting point of development of socialist market economy, application-oriented advanced talents should be cultivated based on the demand of talents in marketing of enterprises in Jilin Province, who should have great comprehensive quality, high innovation ability, great understanding of modern marketing theories and skills as well as the abilities to conduct market survey \& research, market development, sales promotion, marketing planning, marketing management and market integration.

Principles for Construction. The first principle should be the goal-oriented principle. Based on specialized knowledge and the integration of entrepreneurial knowledge learning and practice, the entrepreneurial consciousness, basic quality and ability of college and university students should be cultivated [4]. The second principle should be the principle of integrating specialized knowledge and entrepreneurial knowledge. The achievement of goal of practical entrepreneurial training can't be realized only through several entrepreneurial courses or trainings, which requires students to transform specialized knowledge into specific work abilities for specific jobs in practical trainings and on-job practices and integrate specialized knowledge and entrepreneurial knowledge in an effective way, which should be carried out in the whole process of education and teaching. The third principle should be the principle of making full use of teaching resources in colleges and universities. Under the premise of limited teaching resources, various specialized teaching teams, courses and 
practical training bases should be integrated. Based on on-campus practical training rooms and the goal of cultivating "double-capable" students, practical training for specialized courses, on-job practices in business projects and practical education and training based on the abovementioned "trinity" should be completed.

Thoughts on Construction. Based on the principles of effectively integrating specialized knowledge and entrepreneurial knowledge and integrating entrepreneurial training and specialized knowledge-based training, modular integration of teaching contents originally arranged based on requirements of specialty should be realized by adopting the entrepreneurial demands-oriented principle, for which different specialties can be divided into different modules. Courses for specialty of marketing were arranged based on the goals of making students grasp specialized knowledge and improving their specialized abilities, which generally included compulsory courses, specialized basic courses, specialized courses, optional courses for specialized orientations and practical courses, etc., in which there were very few courses concerning entrepreneurship and most such courses were arranged in the forms of training or lectures given by experts in various enterprises and industries. For the purpose of transforming specialized knowledge into ability for specific jobs and entrepreneurial ability, the original specialized courses should be integrated and divided into market research module, sales promotion module and marketing skill module. From the perspective of entrepreneurial training, in the market research module, the ability of students in seeking entrepreneurial projects based on using of various methods for market research and market demand should be cultivated in addition to acquisition of necessary specialized marketing knowledge, namely that students should be able to detect key problems and entrepreneurial opportunities and demonstrate feasibility of entrepreneurial projects. Training objective of this module lies in improving students' ability in discovering and identifying market opportunities through market research. As for arrangement of the sales promotion module, based on grasping of knowledge about sales promotion, students should be able to formulate sales promotion plan, conduct sales promotion management and realize effective sales promotion of products by using different sales promotion techniques and methods. This module aims to improve students' ability in conducting sales promotion while facing different customer groups. The marketing skill module aims to train students in formulating marketing plan and program, provide field marketing training and cultivate their marketing skills for different types of enterprises, which should be realized by taking a specific enterprise as the example.

Secondly, as for modular curriculum group, task breakdown of specialized knowledge should be realized based on work process [5]. Such tasks should be divided into different scenarios, in which arrangement of entrepreneurial knowledge and courses should be conducted based on standardized process. As for specialty of marketing, scenarios of the market in Northeast China, North China, East China, etc. can be designed based on different markets. Based on industry, scenarios of real estate marketing, retail industry marketing, automobile industry marketing, securities industry marketing, etc. may be designed. Based on consumer, scenarios of high-end consumers, middle-end consumers and low-end consumers can be designed. Breakdown of practical training tasks of marketing in different scenarios can thus be realized in order to make students go through intensive training.

Finally, relying on practical training rooms in colleges and universities, intensive training about key points in entrepreneurial projects should be realized based on entrepreneurial scenarios or projects. After students can grasp the overall situation of entrepreneurship generally, simulated business organizations may be established in such practical training rooms with certain financial support provided by colleges and universities, for which students should be hired to participate in business operation and on-job practice [6]. Under the management mode characterized by independent management and assuming sole responsibility for their profits or losses, students should go through entrepreneurial trainings in order to realize integration of practical training and practical business operation, gather entrepreneurial experience and improve their entrepreneurial ability in practical business operation as well as solve problems existing in business operation through practical training, through which students can complete the entire process of entrepreneurial education comprising of entrepreneurial preparation, entrepreneurial development and entrepreneurial practical 
training during the process of learning specialized knowledge and construct the educational and practical training mode based on the "trinity" comprising practical training for specialized courses, practical training for entrepreneurial education and on-job practice.

Operating Process. Practical training for specialized courses, practice of students and entrepreneurial education should be organically integrated into a training plan system [7]. Based on those practical training rooms in colleges and universities, a relatively complete educational mode of entrepreneurial practical training should be established for the purpose of improving adaptability of students to various jobs and improving their entrepreneurial ability. Specialty of marketing is taken as an example, for which operating method of this mode is described as follows.

(1) Formulation of wholly-integrated practical training plan

Guided by the objective of cultivating "double-capable" students, contents requiring practical training in specialized courses and entrepreneurial theory courses should be integrated into a practical training plan, for which the core works include integration of teaching contents and training subjects. As for specialty of marketing, based on specialized knowledge and entrepreneurial content, contents of entrepreneurial practical training should be integrated to form market research module, market promotion module, marketing module and relevant practical training, and comprehensive teaching plan for practical training should be formulated.

(2) Process of practice relying on practical training rooms

Firstly, projects should be determined and teams should be organized [8]. In the process of learning specialized knowledge, students should conduct argumentation on those projects to be operated in practical training rooms based on market demand. Then teams should be organized based on requirements of such projects. Instructors and employed experts from relevant industries should review business plans for such projects and help students improve such business plans.

Secondly, single-point intensification and preparation for actual business operation should be realized. Based on key points in those business plans and weak links in actual business operation, intensive training for single subject should be conducted in practical training rooms. For example, an automobile marketing office may be established, for which relevant equipment should be introduced in order to reflect the actual scenario of works in 4S stores. Subjects of single-point training include: Market research for products, product promotion planning, product promotion, product marketing planning and field marketing, through which skills and abilities of students can be improved in order to cope with market demand.

Thirdly, guidance should be provided by experts and market-oriented business operation should be conducted. In practical training rooms, actual market-oriented business operation should be conducted by groups of students within a time limit. During such business operation, colleges and universities should provide a certain amount of loan to students based on preparation of colleges and universities and review of experts. Teams of students should realize personnel organization (students should be hired to have on-job practice), construction of organizational structure and determination of responsibilities and power, in addition to which other works such as determination of products and services to be traded, finding of purchasing channels and formulation of marketing strategies should be completed. During the process, a team of instructors comprising of teachers in these colleges and university and from other organizations should be established to follow up such business operation and provide guidance in the whole process. For instance, if a digital publishing house is established, technical software and relevant items should be introduced. During such market-oriented business operation, project teams should consult with the team of instructors in case of any problem, adjust their thoughts on management and solve the problem.

Finally, performance should be evaluated and guidance should be accepted. Based on agreement, a business operation team should pay back the loan from school after the end of business operation in practical training room. The business operation team should settle accounts and make a summary of their business operation process, based on which they should report their operating result to the team of instructors in the form of oral defense and each member of the business operation team should make a summary based on specialized knowledge, entrepreneurial knowledge and practical business 
operation and submit a practical training report to the school. The team of instructors should review such report and determine the result of such practical training, in addition to which the team should provide feedback information and guidance for dealing with all problems faced by students during the whole entrepreneurial process.

\section{Guarantees for Implementation of Practical Training for Entrepreneurial Education Based on the Trinity of "Practical Training + On-job Practice + Entrepreneurial Practice"}

System Guarantee. Guided by strategic concepts of talent cultivation, colleges and universities should grant a certain degree of autonomy in some aspects to various schools such as resource allocation, school-enterprise cooperation and personnel arrangement when coming up with top-level design and consider specialized practical training, practical training for entrepreneurial education and on-job practice as a trinity [9]. Colleges and universities should construct platforms for entrepreneurial practical training, establish support systems and evaluation systems, guarantee implementation of mode of entrepreneurial practical training on the system level, mobilize teachers and students in a sufficient way and thus realize high-quality innovation education of practical training.

Teaching Force Guarantee. Not only does innovation education require instructors to have deep theoretical foundation of instructors, it also requires them to have rich practical experience. It is necessary to establish a stable part-time teaching force comprising of experts of various industries, enterprise managers and government officials [10]. Practical ability of full-time teachers of colleges and universities should be improved through various methods such as on-job practice, training and working on regular posts in enterprises.

Organizational Guarantee. Dedicated departments should be established by various schools, which should be responsible for organization and management of entrepreneurial education based on the trinity of "practical training + on-job practice + entrepreneurial practice". Construction of practical training rooms should be standardized and systemized, especially guarantee of fund used for operation of practical training rooms and establishment of stable financing channels. Equipment in practical training rooms serves as an important condition for guaranteeing result of practical training, so it is necessary to guarantee advancement and practicability of such equipment.

\section{References}

[1] Y. Zhao: Journal of Innovation \& Entrepreneur Education, Vol. 5 (2014) No.1, p.30-32.

[2] L.X. Jiang: Human Resource Management, Vol. 7 (2014) No.6, p.242-243.

[3] L. Xu: An Empirical Study on the Impact of Entrepreneurial Education on Entrepreneurial Intention in Local Colleges and Universities (Ph.D., Chengdu University of Technology, China 2016), p.28.

[4] Y.X. Wang: Journal of Chifeng University (Natural Science Edition, Vol. 16 (2016) No.8, p. 215-217.

[5] C.J. Ye: Youth \& Children Research and Practice, Vol. 14 (2015) No.4, p. 39-43.

[6] D.Y. Liang: Education Teaching Forum, Vol. 7 (2015) No.29, p. 254-255.

[7] Y. Dong, Y.Q. Zheng and J. Li: Research in Higher Education of Engineering, Vol. 34 (2016) No.4, p. 95-98.

[8] Y.X. Wang: Journal of Jixi University, Vol. 15 (2015) No.2, p. 17-19.

[9] Y.X. Wang: Career Horizon, Vol. 22 (2016) No.1, p.39-42.

[10] W.F. Ni and H. Chen: Value Engineering, Vol. 35 (2016) No.17, p.182-184. 